\title{
Arab Women's Autobiography: A Contentious Practice that Elicits Disapprobation, Jeering, Curiosity and/or ... Furor
}

\author{
Samia Kholoussi
}

\begin{abstract}
For the Arab female subject, writing against the dominant discourses, the challenges in the autobiographical undertaking have a particular resonance. Regardless of age group, religious and political affiliation, class identification and socio-economic standing, authoring a text about female life is a disconcerting practice. This study is a critical analysis of the tension-ridden arena which female self-narrative occupies and the premises that have for long gone unquestioned, thus rendering the genre unapproachable for Arab women.
\end{abstract}

Keywords: Arab women, Autobiography, Arab female narrative discourse, Middle East studies

The world-shaking act of telling a woman's life

-Kanafani, Afaf, Nadia Captive of Hope: Memoir of an Arab Woman

Al-kitaka fi lahzat 'uri (Writing at the moment of nakedness)

-Mostaghanami In The House of Silence: Autobiographical Essays by Arab Women

Writers

Theoretical postulations that examine women's autobiography help explain why Arab female autobiography, despite its continuous proliferation, remains a contentious practice. Scholars have probed into the strain of engendering self-representation. In the opinion of Sidonie Smith, androcentric narrative controlling autobiographical discourse obstructed not only the individuality and presence of women but also the impulse to write themselves into literary subjectivity ("Poetics" 15, 42). The 'auto-gyno-graphic' writing that Domna Stanton discusses underlined the extent to which women internalized the patriarchal view in the experience of self, and culture's emphasis on private and public which arise as conflicting arenas once women seek to assert female subjectivities (132).

In inscribing their autobiographies, Carolyn Heilbrun further notes that women suffered for expressing what they "had not earlier been allowed to say" (60). Most challenging, she believes, is the threat the self-text poses to men because it provides "disturbing models for possible destinies of other women" (22). By peeling away layers of closure, the autobiographer compromises the ideal of female destiny that "forbid(s) life to be experienced directly" (Heilbrun 20). Because reticence is one of the conventional expectations of womanly conduct, owning a public voice gives rise to the stigma of fame that brands woman as "abnormal, monstrous" and eccentric (Heilbrun 21). Divulging anger and resentment, Heilbrun maintains, is regarded as a desire for power over other lives which is a right deemed by society as reserved to men only (12). In this respect, Leigh Gilmore professes that confessional technologies, whether literary, social or ecclesiastical, "through which the subject of autobiography is produced ... put women writers on notice" (189). Thus, "the interstices of institutions" and "the margins of hegemonic discourses" are the available sites for female selfdiscovery and self-invention (Gilmore 184). 
In a study of autobiographers with illustrious careers in spheres dubbed as unwomanly, Patricia Spacks observes that their narratives come out as a "confession of inadequacy" (qtd. in Heilbrun 22) and "a rhetoric of uncertainty" and "doubt about the integrity and value of the self" (Spacks 131) prevail. For Bella Brodzki, "matrocentric autobiography" is a perilous terrain pervaded by the fear induced by male authority, and a sense of guilt since the word is "a divine privilege rarely accorded women" (156). Opposing desires are played out between "an overwhelming compulsion to address and an equally strong internal resistance against selfdisclosure" (158). The dilemma is exacerbated by what Heilbrun calls a female autobiographer's "double displacement" (156); the patriarchal world is not generous enough to make room for women seeking modes of self-representation, besides, to Heilbrun, writing and speaking from a "space marked self-referential is to inhabit ... no place" (156). This opinion concurs with Brodzki's belief that any feeling of power derived from occupying the textual space of autobiography is a "delusion" (156).

In addition to cumbersome gender generalizations controlling women's self-texts, "limits of genre" (Gilmore 183) restrict further the sphere of possibility. Given the fact that they "occupy positions of internal exclusion within the culture," Shari Benstock contends that "the question of genre often rides on the question of gender" (148-149). This situation is conducive to what Susan Friedman describes as a woman's "autobiographical disabilities;" if she embraces standard paradigms of individuality and disinterestedness, she surrenders the model of femaleness, while shunning them excludes her text as non-compliant with canon formation. Autobiography, when associated with men's writing, is revered as "crafted and aesthetic" (Friedman 132), but when attributed to women's texts, it elicits deprecatory notes. She cites seventeenth century critique of the Duchess of Newcastle and Lady Anne Fanshaw that persists, though to a lesser extent, in the present times: they were identified as "the first of the two lives types" but the texts and their authors were treated with contempt (133).

The above mentioned critical perspectives highlight a rationale for the discomfort women sense, cross-culturally, in inscribing life experience. Given its objective to make evident and out in the open the events, decisions and relationships that have for long been invisible, female self-narrative has always had a vulnerable relation to culture's central notions. The patriarchal gaze has had a damaging impact on structuring a woman's representation of her life. It confined femaleness to paradigms of gender relations inscribed in the dominant discourse.

For the Arab female subject, writing against the dominant discourses, the challenges in the autobiographical undertaking have a particular resonance. The autobiographical act occupies a tension-ridden arena. Regardless of age group, religious affiliation, class identification and socio-economic standing, authoring a text about female life is a disconcerting practice. Premises that have for long gone unquestioned render the genre unapproachable. The autobiographical pact, mandating the identification of the writing self and the written self, jars with the predominant disposition of shielding the inner sanctum of intimate space from public scrutiny, and conflicts with cultural representations of woman as prudish and self-abnegating. Hence, at a time when gaining social approval hinges upon deflecting rather than emboldening intrusive eyes, autobiography lays bare the securely ensconced caverns of female life and exposes it to public gaze.

In the Arab world in particular and the Islamic world in general, a caution prevails with regards to writing autobiography. Amal al-Tamimi maintains that critics attribute the scarcity of female autobiography in Arabic literature to the fact that it deals with social, political and religious factors and in Arab societies these areas are full of taboos and thus muzzle selfexpression (176). Writing autobiography for 'Awatef 'Abdel-Rahman is a complex process in 
the Arab society. She states, "Until now, the mechanism of the socio-cultural authority chokes the ability to divulge and make public the inner workings of the human psyche" (12). Moreover, "the intimate details of one's life are saved in a black box immune from disclosure and herein resides, for me, the problematics of the boundaries between the private and the public when it comes to writing autobiography" (12).

Farzaneh Milani attributes such apprehension to the unpopularity of practices that in the West have had a favorable impact on the propagation of autobiographical undertaking mainly; Catholic confession and psychoanalytical counseling ("Veiled Voices" 3,6). In the case of 'Awatef 'Abdel-Rahman, writing autobiography, unlike other forms of self-expression in fields such as journalism and research work, is an albatross around the neck. She explains, "We belong to societies where orality is the most common form of human communication ... Moreover, unlike the west, we have not received the necessary training in this craft that would familiarize us with the art of self-writing. In the west, children are encouraged and motivated to keep diaries in which they record daily experience, thoughts and perceptions" (15).

As a rule, 'Abdel-Rahman Badawi declares that the Arab personality is reserved and introverted; "Often inhibited and hardly garrulous about inner feelings" (113). Notably, oral repertoire of popular culture admonishes the penchant for self-acclaim. A common usage of $w a$ 'a'ouzo billahi min kalimat 'ana (God forbids my saying ' $\mathrm{I}$ ') is substantiated by Qur'ānic allusions in which al-kibr (arrogance) implied in 'ana ( I ) is associated with Iblis (Satan), the autocratic Pharaoh and the supercilious Qaroun (435). ${ }^{1}$

In his investigation of the genre of autobiography in classical Arabic literature, Saleh AlGhamdi notes that fakhr (extolling one's personal virtues) is neither condonable nor commendable, and fear of hubris prods the autobiographer to intentionally over-emphasize character flaws and indiscretions (88). On her part, Milani's observation on Iranian memoir writing bears relevance. She declares that "granted the part played by humility, selfcensorship, discretion ("Veiled Voices" 10) ... (and) "avoiding voluntary self-revelation and self-referentiality, most Iranian writers have turned their backs on autobiography" ("Veils and Words" 201). Folkloric adage brands sarcastically a person's self-display as ostentation like 'a peacock flaunting its feathers'. When Leila Abouzeid sets out to record her life story, she is wary of the "pejorative connotation" of "Madihu nafsihi wa muzakkiha" (boasting of oneself) (iii). In his memoirs of his illustrious career in journalism, Moussa Sabri was advised to include details of personal experience to which he retorted: "But talking about the self is an abominable practice!" (5)

Ideologies embedded in Arab cultural-political history render self- inscription a formidable task. For long, writers resorted to the early predecessors (al-salaf) as exemplary models to learn from and imitate, thus discouraging individual introspection as tajawuzi (transgressive) and disruptive of conformist thinking (al 'usuliyah / 'usuli).2 In this respect, Fatna Sabbah presents a critical reading of orthodoxy showing that the believer is not expected to manifest an individual will, and "any attempt to change the existing order ... is bida (innovation)" that is condemned as errant behavior (118). Moslem cultural order, as she puts it, mandates that the believer "invest(s) his energy, not in attempts to express himself, but in attempts to decipher the discourse of the almighty ... (he) is fulfilled not by expressing himself, but by making his own expression (that) of ... God" (118). Moreover, 'Abdel-Rahman Badawi observes that in the Arab cultural landscape, "the focus of the autobiographical project on the self is opposed to the communal proclivity prevalent in the east" (113). In his discussion of the collapse of unifying grand narratives that shaped the Arab discourses in the fifties and sixties, Kamal abu-Deeb denounces the rise of individualist voices as one of the marked effects of the fragmentation of 
Arab organic wholeness in the social, cultural and political spheres (339). On her part, Suad Joseph's deliberations on her theory of 'intimate selving' examine the foundational framework that underwrites notions of self in the Arab cultural experience as "intersections of selving within family systems" (x). Reflections on the genre of autobiography in Arab belles-lettres lead 'Abdel-Hussein Sha'aban to speculate that undoubtedly tribal affiliation has its influence on the refutation of individualism and independence_(www.ahewar.org). Thus, indulgence in the affairs of the self and doting on the particular and personal have been reprobated as deviation from collective aspirations. According to Daphne Grace, autobiography is preferred by "only those Arabs who have adopted a 'Western' lifestyle" that espouses the concept of separatism, going outside or above the community (184). Whether it is an act of defiance or self-assertion, autobiography, as Grace puts it, is contrary to the corporatist orientation of 'umma (nation) that has once qualified the lives of Arab men and women (184) since it situates individual identity as distinct from the collective within the group (185).

In fact, autobiography is culture bound and in the Arab context, it does not lend itself favorably to writers. A common structure of feeling determines the conventions of self-representation in written texts. Individualistic impulses are expected to remain inaccessible to public perception. Manifestations of non- conformism entail a betrayal of deep-seated cultural values, and thus carries the risk of social rejection. In the context of Arab ethos, maturity valorizes the integration of self and others, and heeding responsibilities towards kith and kin. The relational notion of the self has for long constituted the rhetorical ground of appeal. Since individual identity as a primary cultural value is the sine qua non of autobiography, the socio-cultural Arab reality fosters a climate that is uncongenial to the immersion in autobiographical disclosure.

For prospective autobiographers, the lower order assigned autobiography in typology of humanities has been disheartening. It is noteworthy that autobiography, for an extended period of time, has been a dismissed as subpar literature, and in Arab academia, it has occupied a dubious position. Several Arab academic disciplines have not valued personal narrative as worthy of critical study claiming that, as Hoda el-Saddah puts it, it does not meet the scholarly criteria of "scientific distance from subject matter" necessary for historical writings, nor does it comply with the pre-requisites of aesthetic impersonality expected in literary composition ("Reconsidering" 450). In his speculations on the self-narratives of Moroccan women, Mohammad el Dahi points out that "scholars exclude from critical evaluation life-text (récit de vie) since it subsumes under bad literature (la mauvaise littérature) devoid of literary merits, often slighted as deficient in literary credentials and written solely for entertaining the reader with 'factual' life stories and adventures". He adds that "critics disdain this kind of writing and allot no value to its practitioners who, in most cases, belong to the mediocrity among the literati whose writing is off limits to what is considered professional literature (La littérature professionnelle)" (www.minculture.gov.ma). To a similar degree, Leila Abouzeid points out that "the thinking goes that everyone can write about his or her life," and such writing was not classified as a literary genre, since "literature meant the lyric, the poetic, and the fantastic" (iii).

In fact, for decades, autobiography has been overlooked as raw and lacking in sophisticated structure, rhetoric of language and novelistic poetic forms. In the ranking of genres worth analytical examination, it was at the bottom of the scale; a lesser form lacking in creativity and craftsmanship. At best, the lure of factual stories attracted leisurely reading captivated by the lives of celebrities.

Additional hurdles render writing an autobiography a grueling task. Customary observance of decorum and civility forces writers to be scrupulous in the selection of the incidents they 
narrate. Sha'aban maintains that upon embarking on an autobiographical enterprise, the writer, regardless of gender, struck by the interdictions of propriety, senses the rigor of a burdensome undertaking (www.ahewar.org). Youssef Al-Sharouni points out that the struggle to present a truthful account of the past leaves autobiographers in disquietude about the reaction of members of their community (82). In this respect, autobiography entails ethical issues. Given the tension between the good and the harm of life-writing, Paul Eakin finds it necessary for authors to consider the moral responsibilities of the practice, and resolve the conflict life-writing poses between right to free self- expression and right to privacy (15). In crafting memoirs tackling human relationships, Claudia Mills believes that authors are attentive to expectations and obligations. She states that they "agonize over how much of this relationship and experience they can reveal in their work; and how to honor obligations to loved ones" (101). In measuring injuries and benefits in writing one's own life, she poses several questions, "If kith and kin provide authors with material, are authors entitled to use this material? (101) ... How can one value one's loved ones appropriately while also drawing on their lives for one's work?" (104) Resolving the tension between the two commitments is a crucial debate in self-texts.

In delineating "the moral geography of their lives" Valérie Baisnée maintains that narrators realize that "various ethical acts lie at the heart of autobiographies" (135). Autobiographical stories demand a sense of responsibility (Baisnée 134) since stocktaking and giving an account of oneself is at the same time making oneself accountable to another. For Smith, the autobiographical ethics in narratives of personal exposure encompasses in addition to moral responsibilities, "what subjects and audiences know of each other ... how they comport themselves ... the positioning of audiences during and after the subject's life-time, the subject's relation to biographical accounts and extra-textual evidence" ("Reader" 3).

Since others are intimately woven in one's life story, the question that erupts is whether lifewriting is a form of trespass. Generally, autobiographers heed dragging into their narratives the lives of those they know. Given that the subject is a relational being, the ethical implications of telling one's life are taken into consideration.

Recasting the above perspectives for the purpose of examining Arab female autobiographers, a host of issues come to the fore, mainly; the imminent threat of repudiation and ostracism that intimidates Arab women if they write about others with disrespect or indecency. al-Tamimi deliberates over the ethical bearings of life writing as a topic that deserves further scrutiny, and maintains that "disclosures in Arab female autobiography lead to an important question regarding the autobiographer's transgressions and the protection of others against unwanted exposure ... and whether or not encroaching on the affairs of others can be considered legitimate in autobiography" (187). She asks, "What is acceptable or unacceptable when it comes to discussing affairs about self and family, and what would restrain an autobiographer from publishing information about others? In divulging intimate details, is the autobiographer allowed to go beyond the circle of family members?" Ultimately, in her judgement, what counts is "the extent to which any revelation and/or revelation about others' lives serves a purpose in the narrative and the extent to which it is instrumental in achieving the objective of defining Arab female selfhood?" (187)

In autobiography, family and friends are crucial in the experience of the narrator thus the text would inevitably engage their lives yet, al-Tamimi observes that "it is still debatable how far the self-narrative may delve into the privacy of others" (187). Sense of self, central to autobiography, is closely connected to morality. The ways we live our lives includes selfregarding and other-regarding concerns, and thus, "ethics becomes a basic preoccupation" 
(187). In her mapping of the ethics in the autobiographical act, al-Tamimi ponders over the grave consequences entailed by disclosing confidential information about other lives. ${ }^{3}$

For autobiographers, the awareness of the good and the harm of life-writing is associated with the question of truth. In this respect, Smith contends that self- narration is so written that it cannot be read as either factual truth or simple facts. As an intersubjective mode, it lies outside a juridical model of truth and falsehood ("Reading" 13). Additionally, Baisnée maintains that autobiographers produce their own version of the pact of truth in the first lines of their texts; and that 'swearing the truth' may vary according to the narrative moment when it is uttered (7).

Although it is a controversial issue, telling the truth seemed the obligatory topos of prefaces. In an autobiography that is expository and rather prolix, Maha Fa'iq 'Attar repetitively promises to adhere to accuracy in her account. She prides herself in the ability to abide by such decision considering it the greatest strength of her text. Digressions in her life narration speculate on the criteria she set for her practice: one of which is "to give full attention to detail in order to produce a faithful account" ('Attar 9). Nonetheless, she excludes from this writer-reader covenant any attempt at engaging in shaming revelations or making disrespectful innuendos that may embarrass others stating that she "would rather forfeit the value of truthfulness than enrage or offend kith and kin" ('Attar 9).

In writing about friends and family members, authors can reduce the cost of dragging their names in the self-narrative. Claudia Mills suggests less daunting ways that disguise them and protect their identity such as resorting to fiction, withholding the person's name, changing revelatory details whenever possible or making up most of the events that take place (Mills 114-119). It is notable that when Zeinab Fawwaz incorporated autobiographical elements in Husn al 'Awaaqib (The Happy Ending, 1895), she, by design, changed the names of individuals and places "to avoid involving some of the people who are still alive, and protect the good name of many families whose sons desecrated their honor" (Fawwaz 37). Opting for fictionalization of factual stories, her text minimizes the cost of the adverse effects incurred by violating confidentialities. Alternatively, the autobiographies of Fadwa Tuqan, Layla 'Usayran, Evelyne Accad and Hanan al-Shaykh allude to relatives and acquaintances starring in the life accounts by their initials or by using cognomen, sobriquet, nicknames or ellipsis. Given their solicitousness concerning social seemliness and punctiliousness, they concoct an ad hoc narrative design made up of an assortment of insinuations and intimations that are subject to double signification. In this fashion, equivocation has assisted in the flow of their reminiscences.

In fact, the values inhering in ethics that governs the practice of life-writing are necessarily culture-specific. The compulsion to abide by their imperatives is mandatory regardless of the gender of the author. Arab women, in particular, engage in a balancing act between trust and betrayal calculating the benefits and costs of life-writing in order to maintain allegiance to protecting privacy and faithfulness to truth. Since the narrative of oneself is "outward-directed act" (Butler 81) and the 'I' does not belong solely to the self (Baisnee 135), the responsibilities incumbent on autobiographers to take into account the other is a central concern. In any case, the guiding value is respect for the moral obligation that the display of experience entails. Moral approbation and a sense of propriety superintend the autobiographical consciousness. Eschewing antagonizing or alienating others is the criterion. Since candor and un-embellished truths backfire, caution and prudence become expedient measures. Unpremeditated remarks may wreak havoc leaving the autobiographer in restlessness about adverse consequences. 
For long, autobiographical undertakings have been unappealing due to their association with the culture of confession and the reductive overtones with which it is laden. In her examination of the logic of confessional discourse, Sawsan Nagi points out that the culture of female confession encompasses discursive and non-discursive alternatives that include autobiographical silence, and non-confessional autobiography (73). Irene Gammel's (1999) historical perspective of the politics of confession conveys the association of confession with femininity cross-culturally (1). When this proposition was vocalized, it stirred contentions and inspired heated debates.

Given the diatribes in the internal dialogue within Islam regarding the woman question and self-publication, the literary newspaper, Akhbar al-Adab, conducted an interview with the $M u f t i$, the official expounder of theological decrees, regarding his opinion of Islamic adjudication regarding this issue. He responds with unflinching determination that when it comes to women's writing about personal experience, literature of confession is harram (religiously forbidden) since it would be a deliberate exposure of private life to al nazar al mubah (permissible to public gaze). Ironically, the Mufti, seeking to improve upon his allegation, professes to his interlocutor, "Mind you, what I'm saying is not censorship and should not be considered as restricting the freedom of expression. I'm only concerned about the sanctity of family life and conjugal relationship that Islamic values enjoin us to shelter from the intrusion of prying eyes" (qtd. in Abu el-Naga 117). In a scholarly exploration of the nondire in the Arab discourse of female corporeality, Aminah Ghusn offers a counter- argument stating that "women's writings and in particular those about the self have never been a preoccupation of the Islamic belief system ... Exhortations interdicting female self- expression are impositions of personal opinions on the scriptures interpolated in the text thus giving false interpretation" (79). Moreover, Qamar al Kilany discusses confession as a practice acknowledged by Islam, and identifies such literature as an art that some of the Qur'ānic verses sanction (al-Tamimi 85-86).

The aforementioned rhetoric indicates the multi-faceted contentions disputing understandings of accepted doctrines. In their endeavor to create a feminist theology that gives eminence to female point of view in postulations of the divine, feminist-oriented theorists undertake to unsettle the male-dominance theology of Islam. ${ }^{4}$ Conservative trends of thought impacted female practice of self-referential writing as well as positions of enunciation that women occupy in narration.

In his study of autobiography in Saudi Arabian literature, 'Abd-Allah al-Haydari is harsh in his judgment of confessions of female authors. Confession, generally understood as an occasion for avowal of transgressions, is considered by him a luxury that only men can afford. Such double standard promised forgiveness to men for their sins while branding female confessors social pariahs for equivalent offenses. He cites the case of Fadwa Tuqan, brazenly publicizing her addiction to smoking as unacceptable for a woman, and impertinently identifying herself as secular as disrespectful. Such shamelessness in female confessions al-Haydari attributes to ignorance (608). ${ }^{5}$

On her part, al-Tamimi makes a suitably cutting retort to al-Haydari's accusations. She comments that, as far as smoking is concerned, several autobiographers such as Layla al'Uthman (42-43) and Layla 'Usayran (250) express their regret for being captive of this bad habit (184). She elaborates, "We cannot describe confession in autobiography as insolent or shameless unless it is meant to promote vice and arouse illicit desires ... those such as Fadwa's and others are contextual ... In confessional narrative, it is expected to tell the truth about oneself which serves the literary function of achieving a transparent interrelation of author 
and subject unlike the crafted and constructed self in autobiographical narratives" (184). alTamimi objects to al-Haydari's viewpoint, and professes that he "is passing a moral judgment and this is not the task of the critic, since the writer of autobiography is not on trial ... a confession made voluntarily is her way to confront the self and others; it is an act of bravery that merits admiration" (183). In fact, al-Tamimi believes that confession for women autobiographers has a crucial purpose. She explains, "Our job as critics is to judge the value of these confessions to the extent to which they are utilized in realizing the objective of the autobiographical undertaking, and the revelation of the image of the autobiographer" (182).

Dubbed as a gender-specific discourse, confessional autobiography launches incisive feminist critique. In her examination of the complexity and multiplicity of representation of female subjectivity, Shereen Abu el-Naga exhorts Arab women to refrain from referring to their selfnarratives as confessional accounts. Since female confessions evoke episodes of scandal and disgrace, authors need to avoid deploying the rhetoric and rituals surrounding the act of confession. Abu el-Naga believes that eschewing the undesirable implications and derogatory connotations of the term can also work as an effective mechanism to deflect possibilities of censuring the female self-text (117). Unlike male autobiographical practice in which confessional paradigms are indispensable aspects of the process of self-discovery and selfunderstanding, Abu el-Naga maintains that situating female self-narratives within the framework of the confessional plagues the author's life with assaults and denigration. Referring to their self-narratives as confessions conjures up all dismissive overtones with which the term is laden, and renders the narrative a target of attack $(34,45,117)$.

At the outset of Fat-hiyya al 'Assal's autobiography, she professes a hesitancy to excavate her memories. Turning her gaze inwards, scrutinizing the self and delving into the caverns of personal life would not be an open disclosure since, as she puts it, "much of that past I have no intention of unravelling at all; there are cherished reminiscences that one prefers to keep securely ensconced in the vaults of the soul, protected from prying eyes" $(6, \mathrm{I})$. In a like manner, Samihah Kharis inserts a caveat in the introductory chapter of her autobiography that shows reticence. She states, "This text is the story of places not the story of my life, it has nothing to do with what I passed through as a person. I will always hide the story of my life; I have never written it and will never ever do so, not in my novels and not in this text." She adds, "And if I ever dare to embark upon this kind of peculiar task (confessional writing), I think I will conceal a lot, and intentionally forget even more ... I don't have the courage ... to write my autobiography" (10). However, later reflections reveal a change of heart dictated by some internal imperative. Kharis declares, "I write this text as I go through life, a mere passerby, a bystander. The details and features of the place are inextricably woven into every aspect of my development, the lives of others are intertwined with mine, the events that map the place and determine its characteristics spin the incidents that form my life experience" (11). Mulling over her creative writing, 'Aisha Abou al-Nour admits, "I write as I live and live as I write without donning masks or masquerading" (35). Yet, when trying to classify her writing, she states: "I'm at a loss ... Is it autobiographical or confessional practice?" (Tawfiq 23)

In fact, women's practice of self-inscription as confession perpetuated various stereotypical female roles of the suffering, helpless and passive victim. It reiterates the conventional image of female psyche as fragmented and needy, and connotes the enactment of penance and hence self-accusation and self-castigation. The autobiographer's fluctuating stance between reserve and openness signals an awe of the serious consequences of foregrounding intimate details no matter how significant they may be in serving the authorial intent, the narrative process and the autobiographical purpose. Significantly, perceiving female autobiographies as confessional modalities written to divulge shameful secrets prompted the development of maneuvering 
strategies devised to avoid incrimination maliciously intended to position them in conventional frameworks of shame and disapprobation. The resulting poetics interrogates the tensions between public and private, art and life as well as self and society.

For the most part, self-inscription has always been the least tolerable of female literary representations. Discussing the rhetorical stances of Syrian female narration as it shifts between unequivocal self-exposure and auto-fiction, Majidah Hammud declares that the propensity to "speak outright; candidly, undisguised and in the first person, is a dangerous undertaking" (60). In this regard, "Aisha "Abel-Nour remarks, "The textual process of delving into the shadowy corners of life experience disinters forbidden territories interdicted by the hidebound traditions and centuries-old cultural and religious authorities. This would inevitably hurl the female writer to her doom" (qted in Tawfiq 36). A self-referential mode of writing can be a daunting task; Ghadah a-Samman states, "Here I am; for the first time in my life I am writing down my memoirs in the first person and telling about myself, and I'm fully aware that I'm speaking about myself, rather than writing something that is half fact and half fiction. I am not afraid that anyone would know that I'm speaking about myself, and I am also not afraid of perpetrating this act" (487). Her repetitive outcry denying any fear acknowledges rather than dismisses a sense of trepidation about an anticipated castigation.

In his critical survey of Arab women writings in North Africa, Mohammed Berrada announces, "No text produced by North African women bears the designation 'autobiography' on the cover, but there are at least three works that qualify as autobiographical novels by virtue of their form and style" (250). In this sense, Leila Abouzeid introduces the Arabic version of Return to Childhood with a revealing commentary. She states, "Writing my autobiography was simply unthinkable because first and foremost, I was a woman in a society in which a woman has been historically enslaved and silenced, not to mention that speaking about private life would be like stripping naked in public." She goes on to recount her beginnings as a creative writer, "When I wrote my first column in the late sixties, I didn't even have the courage to use my real name. And when I wrote my first novel, I left out the name of the country of the heroine. In other words, I had to wait long years before I dared to inscribe my autobiography" (4).

In underlining the power of the word in influencing the cultural landscape, Meredith Tax explores forms of gender-based suppression, one of which takes place within the family where "Fathers or husbands ... appropriate the work of their daughters or wives because they do not wish them to have an independent identity, and feel the work of women ... properly belongs to them" or disregard or destroyed manuscripts because they reveal "family secrets" (21). Apprehensions of this nature interfered to delay the publication of the autobiography of Abkar al-Saqqaf till the year 2001 although the fully fledged version of the text has been ready for the press since 1962. Leery of their unabashed defiance of conventional mores, collections of autobiographical writings by Mai Ziyadah and Doria Shafik have been held captive by their families who were reluctant to release them for public perusal. Faced with the menace of social ostracism, Galilah Rida grapples with contingent liabilities as an unruly woman in a conservative family; her self-narrative recounts the uproar her brash allusions to a lover's kisses stirred up in the media and the outbursts of family anger and reprimands (Rida 84).

Upon researching Arab female authorship, Rosa Hassan discovers that there is hardly a text without a cost. Developing the gift for letters into a vocation is a risky venture that exacts its toll on its female practitioner. Hassan finds that for the most part, women are incriminated rather than appreciated for writing. It endows meaning and sustenance to life yet inflicts misery on them; society heaps its frustrations on the female trespasser and jeers at her artistic composition dubbing it "the literature of spinsters and divorcees" (www.pewesr.org). Several 
critics corroborate this point of view. Discussing the opposition that Fadwa Tuqan encountered in her perusal of literary aspirations, as recounted in her autobiography, Dalya Abudi states that a woman pays the price for embracing her talent; battling "formidable social and cultural obstacles rooted in patriarchal myths and assumptions about herself as a woman and writer" (107). Tuqan was surrounded by "a society of sharp tongues and unceasing gossip and backbiting" (Abudi 95), and not even the educated women in Nablus showed her "a friendly spirit" (107). Even 'Â'ishah 'Abd al-Rahmān (Ibnat al-Shati') who complied unreservedly with conservative religious teachings, recollects her trepidations when she decides to publish her writing in a daily paper. It seemed an intrepid deed; she states, "I thought I hide behind a pseudonym so my father would not find out and prevent me from communicating with a circulating newspaper; given the customs of the day, it was unthinkable for a woman's name to appear in print" (60).

Judging by what he discerns as a trend, Ashraf Tawfiq's series of interviews with novelists from different age groups and political affiliations, leads him to infer that there is an obvious connection between a woman's literary métier and marital discord (27). After initially contesting such observation, Mona Helmi acquiesces and concedes that the stability of domestic life is often imperiled since it is hard for "the male ego" to comply with the spouse's commitment to advancement of a career, let alone a husband's refutation of a wife's public visibility and fame which he believes subject their relationship to calumny (Tawfiq 43).

There is so much at stake when the autobiographical act is committed by an Arab woman. For long, the incursions of women upon a literary market, traditionally designated as a male domain, have rendered them martyrs to their calling. Moreover, Arab women realize that husbands prefer the fondling of the queen of love and the beauty of a face to the intelligence of a Minerva. However, once possessed by the demon of writing and the passion of artistic creativity, several women tend to reshuffle their priorities.

In an autobiography that is appropriately entitled, Walking through Fire, Nawal el-Sa'adawi recounts a situation in which she had to choose between her literary calling and her husband, and she declares that she unwaveringly opts for the former and with resolute determination (190). Decades later, the autobiographical persona in Sahar el-Muji's Dariyah deals with an analogous problem; she is accused by her husband of self-consequential and narcissistic enthrallment by her personal ambition. She follows in el-Sa'adawi's footsteps and sacrifices marital bond on the altar of artistic creativity. The torments of the despondency of divorce and the alienation of her children do not placate her intransigence.

For the most part, the titles that authors choose for their self-narratives have designative and connotative functions that, as Gerard Genette argues, controls the thematic development, and one's reading of the text (708). Discussing the power of the title, Ibrahim Taha depicts it as pretext, the part which is the first to welcome the reader and is separated from the body of the text. And, in essence, it also features as post-text being the last station to which the reader returns after his contact with the body of the text (66). In her autobiographical meditations, aptly entitled Imra'at al-araq (An Insomniac woman), Mīrāl al-Ṭahāwī explains in greater detail the trials of laboring to get her writing done and the shields she erects to protect the creative spirit. Her self- text documents her commitment to her craft and her artistic ambition. She states, "The men in my family were not accustomed to and could not understand why anyone would be enamored with and indulge in writing, nor were they even receptive to learn the worth of this craft." A pattern of fear becomes her second nature; "I am the offspring of a tribe that lives in constant fear surrounded by taboos ... just like all the other village girls, when I began writing, I was obsessed with apprehensions of speaking out and divulging my thoughts" 
(61). It is a constant struggle to stay in contact with her muse, "After I put my son to bed, I wonder if I would be blessed with the inspiration for writing torn as I am between the burden of house work and the fear that seizes my pen since I am a woman vulnerable to being misread and thus indicted for what I write" (56). On first publishing her work, al-Ṭahāwī was asked about her "rituals that accompany the process of creativity" (60-61). The question haunted her ever since. She reflects, "I abide by the same rituals from beginning till end and always haunted by dread; my writing is encrypted to protect my articulations of passion, estrangement and anxiety from being spotted by my inquisitive relatives" (60-61). Significantly, she remarks, "If fictional writing that is generally considered as a figment of the imagination desecrates a woman, can you imagine how perilous it would be for her if she chooses to write about factual experience" (60-61). Undoubtedly, staging of the self through textual disclosure would lead to calamitous consequences.

In fact, in inscribing the self, Arab female autobiographers share the difficulties men face in addition to a constellation of obstacles that are exceptionally cumbersome owing to gender issues. The diverse postulations on autobiography by Arab woman epitomize the complex dynamics of cultural politics ${ }^{6}$ impacting women's status in Arab reality. Located in the ferment of ideological currents, it is caught in the turmoil of the antagonistic interaction of the secular and the religious. For decades, it has been cast in a negative light for the alleged affiliation of its early practitioners with the women's liberation movement, and their objection to religious interdiction of women's visibility and agency. ${ }^{7}$

By and large, Arab women have been without a self-text. The specter of Derrida's phallocentrism haunting the construction of meaning preponderates and threatens female right to first person perspective. Expatiating on critical junctures in Arab women's relationship with writing, 'Abd-Allah al-Ghudhami states that the literary discipline that governs self-portraiture perceives the generic 'I' as masculine (79) and authorship is associated with the phallic of authority and the patriarchal institution of property and law (21). Researching the belated recognition of women's autobiography, Mohamad Mo'etasem infers, "The space of the female 'I' has been colonized by men" (21). Hence, engaging in self-narration is regarded, as 'Afif "Uthman describes it, an act of "double transgression" (www.terezia.org) wherein the female author wrests control of an androcentric genre, and seizes the domain of female representation. From the standpoint of Fadia Faqir, the situation for women is "a double jeopardy" $(12)^{8}$ on account of both gender and the genre adopted for self-expression. ${ }^{8}$ Speculating on the paucity of Arab female self-narratives, el-Sa'adawi blames systems designed to invalidate women's experience and subordinate its concerns. She contends that, in the critical guild, the recurrence of the pejorative epithet 'insignificant' to describe women's writing "recapitulates the predominant attitude of detractors when a woman's life-narrative is the topic of discussion and evaluation" ("Qadaya" 49). It is one of the forms of organized suppression in which critics do not take work by women seriously. Projects of Arab female enunciation may not have been banned but, time and again, they have been neglected and undermined.

Admittedly, the female autobiographer is constantly grappling with the anxiety of authorship. Absenting women's contribution to the genre in official platforms or discrediting it as unqualified has fostered a sense of self-deprecation and low self-esteem. In re-appropriating the position of the autobiographical subject, the Arab woman felt that she is encroaching on a cultural tradition typified by a heavily coded process of masculinization; and thus she is bound to battling a history of cultural inscription of the subject as male. 
Equally important, exclusionary practices of the literary apparatus situated textual renditions of the female self outside the canon of normative life narration. The entry into the autobiographical domain has been reserved to men who were privileged with the prerogative to do the scrutinizing of both the self as well as the female 'other'. In their monopolizing the narration of women's experience, they imprison women's existence in stereotypical molds and pre-conceived formulae. Representation of female lives, whether descriptive or prescriptive, has drawn on the same signifying codes that designate traditional constructions of femaleness and by re-inscribing them, they are perpetuated, reinforced and eventually sanctioned.

The autobiographical subject is enchained by a 'Gordian knot' to a web of traditional impositions and a value system that regulates culture and has the effect of institutionalizing female consciousness. Fadwa Tuqan's autobiography marks a watershed in the history of modern Arab women's self-narration, thus several critics use it as a point of departure to formulate a theoretical approach to the above postulation. Nayef al 'Ajlouni's scrutiny of the text leads him to conclude that, as a rule, the personal experience of the contemporary Arab woman is punctuated by a catalogue of socio-cultural inscriptions that regulate the narrative process. Jaber 'Asfour attributes the critics' neglect of autobiographies written by women to two reasons: "One is social and the other is artistic. Because a woman in the Arab society is shackled by taboos, her self-expression is limited and she is restrained from revealing; given that autobiography by necessity tackles the very same prohibited issues ... Besides, considering the absence of female role models in this field, she would never be able to produce an autobiography of the highly artistic standards of Taha Hussein's The Days, or compare to the creative writing of Naguib Mahfouz" (qtd. in al-Tamimi 176).

In an endeavor to formulate a layout for a discourse of Arab female narrative, Zuhur Garam indicates that the textual space that the female 'I' occupies is impacted by a legacy of female oppression (58). Despite her appreciation of the autonomy and sense of individuality acquired during her long stay in Europe, Wédad Zénié-Ziegler yields to the fact that "in many ways (she is) still profoundly bound up with ... traditional values" (135). She resigns herself to an indisputable position that she is "a product of the society, the history and culture" and whenever she thinks of refuting mother culture, an "obstructionist mechanism intervenes" (135-136). In delineating the presence of Arab women in the contemporary literary scene, Nazik al'Araji shows that no matter how vociferous a writer is in asserting her freedom, she is still restrained by a deeply engraved discourse of gender enculturation prevalent in Arab societies $(17,32)$.

As a matter of fact, in Arab culture, construction of gender occurs through the workings of ideology identified in Althusserrian terms as the system of beliefs, practices and assumptions that work unconsciously informing every aspect of daily life, and go by unexamined and invisible. The autobiographer, consciously or unconsciously, reads the self through inherited and hidebound ideological components that constitute major locations in the institutionalized mappings of Arab female identities.

Undoubtedly, Arab female self-representation is multiply determined; understanding it relies upon coexistent structures. The complexity of the Arab female self is best described by the concept of over-determination. Various forces are active and a vast accumulation of psychodynamic factors come into play in the shaping and the developing of the self. In addition to factors such as class, age, ideological leanings, political loyalties and rural or urban setting, the female self is embedded in a context of both patriarchal social order, and longue durée values, customs and traditions. Bounded by gender conventions, female figures are coerced into invisibility, passivity or at best, situated in backdrop settings as enablers of male action. In 
this context, restrictions ordained by society are mandatory decrees with serious penalties attached to their violation.

In patriarchal society, the subordination of women necessitates the silencing of their voices. Thus, gender-based censorship is essential in order to maintain intact the institution of patriarchy. Women writers, breaking the silence about female sexuality, gender relations and socio-cultural malaises that afflict women's lives, become a threat once they disrupt the status quo of gender hierarchy. The panoptic surveillance exploits puritanical sentiments to deny their presence and absent female agency.

Societies gripped by religious fundamentalism discourage woman's heterodox views and incite fear and anxiety to keep her in her 'proper place.' In Algeria, suppressive policies are conducted through death threats. In her personal testimony, Ahlam Mostaghanemi chafes at the absurdity of the mighty censor. Her furious denunciation breaks out with a bitter sneer, "Every book awaits a checkpoint searching (our) thoughts, interpreting (our) dreams, lying in wait for (us) between sentences ... We used to dream of living one day because of what we write, we now dream of not dying one day because of what we write" (87-88). In her confrontation of religious zealots "standing tall" (Messaoudi 7) and unbowed, Khalida Messaoudi's reflects battles on multiple fronts. She reacts to the imams hurling curses at her from the mosque loudspeakers as a "sister of Satan" (Messaoudi 1) by adopting rituals that defy all what the fundamentalists prohibit. She states, "I didn't take all this very seriously -until in the space of a few days, the fundamentalists attacked the leading intellectuals they had targeted, killing them in front of their apartment buildings" (1).

For Zuhur Garam, the monological discourse of religious demagogues and conservative politicians, and the free activity of creativity are contrary currents that run in opposing directions. Her treatise sarcastically, entitled, 'a guest of censorship', is a critical analysis of the range of cultural and social mechanism designed to ensure the acquiescence of women writers. Garam presents her argument through probing the case of Laylá al-'Uthman who was convicted by Kuwait's Misdemeanors Appeal Court of the crime of breaching public decency with a pen.

For Garam, Layla al-'Uthman was convicted for presenting anti-patriarchal view of sexuality. al-'Uthman's revisionist perspective "adjudicates on prevalent social constructs and underlines absented and ignored social malaises" (Garam 56). Garām argues that the charges against al'Uthman were mainly gender-based and the attacks on her work are affected by gender; al'Uthman dared to tread on masculine ground dealing with issues reserved for men, and thus was regarded by the law of the land as a trespasser. Her vision has opened up new horizons and alternative possibilities that destabilize the power structure of an established system. For the trial committee, questioning of age-old conventional practices, and overturning the predominant ways of thinking instigates insurgency that disrupt law and order and thus deserves to be penalized.

To Garam, al-'Uthman was indicted for charges that patriarchal society accuses female, not male writers. al-'Uthman's narrative is 'immoral' for re-defining femininity and masculinity, and love and desire all from a gender-sensitive perspective, woman becomes the subject, a desiring and acting agent, independent and autonomous, and physical desire is re-envisioned as synonymous with passionate love while the concept of manhood is questioned and challenged. al-'Uthman's narrative offers resistant readings that differ from commonly accepted interpretations and re-conceptualize traditional concepts. 
The situation is complicated for women who dare to write about the body or sex since traditionally female voice, dubbed as 'awra, is associated with her body, thus "the pseudonym is instrumental in prevaricating the executive organs of the regime hounding independent minds" (Garam 21). Garam maintains that stifling a woman's voice that embodies her consciousness, awareness and perception, and incapacitating her abilities to express herself constitute a deliberate killing compared to female infanticide in the Jahiliyyah period (31).

Speculating on the experience of al-'Uthman, several questions erupt regarding "the endeavors of authorities to harness creative imagination in order to make it comply with its mandates" (Garam 33). The question that preoccupies Garam is: "What is it that makes authorities so wary and fearful of the creative activity?" (5) They succeed in controlling publications and enforcing laws to ban books. Yet, as Garam asks, "Can the regime confiscate the memory of readers who have already bought and read the works?" (17) She adds, "Creative imagination works in mysterious ways and sprouts up from hidden corners in our being, so how can society put on trial that over which no one has control?" (17)

In Garam's treatise, the theme of censorship in relation to female creativity elicits a number of problematic topics mainly; the role of the creative act in perpetrating subversion of preconceived notions and disturbing established norms and institutes instead alternative values, the force of the imagination to intervene in state institutions, the agency of the writer's critical standpoint in revising power relations of dominance and submission.

The case of al-'Uthman, Garam argues, draws attention to the propitious impact of the culture of fear and silence on creativity, and "the way it can act as a source of opportunity prompting female imaginative powers" (101). In this respect, Leila Ahmed notes the intellectual vibrancy in Egypt at the height of repression under Nasser's rule observing, "I began to wonder whether there weren't perhaps some unintended benefits of having one's freedom of thought and speech threatened ... (it) made one prize and understand all the more acutely how important, how vital ... to one's life and well-being it is to question and reflect on and openly share one's ideas" (301).

For Garam, the validity of this observation is embodied in al Muhakamah (The trial) in which al-'Uthman documented her ordeal laying bare the absurdities of the evidence presented in court. The narrative recounting this distressing episode portrays her indignation for being unlawfully flayed for imputations of obscenity and intentions to corrupt the minds and offend public taste. Significantly, al Muhakamah broaches larger issues of "female creativity and liberation" (Garam 101). It is in itself a declaration of the right to speak out.

In fact, suppressive measures on the part of police states have instigated a course of action that alternates between defiance and maneuver. Refusing to make compromises to mainstream publishing industry, Ghadah a- Samman sets up her own publishing company in 1977 printing and circulating her work without editorial interferences. Alternatively, Hamidah Na'na resorted to self-exile. She states, "Despite the piercing pain of this decision, I left my homeland because they took away from me my freedom: the sap of life" (92). Samar "Attar reflects on the relationship between translating and censorship: because she was blacklisted for braving the patterning of thought (tanmeet), she resorts to translating her work as "one of the strategies to assert a voice that has been suppressed" (Translating the Exiled Self 134). ${ }^{9}$

Self-censorship is pervasive among women, and Tax defines it as "holding-back inside when one cannot face the consequences of speaking the truth" (22). In this respect, Smith proclaims that the autobiography of the female self is a battleground of clashing forces wherein the 
private voice labors to "strip away the heavy layers of self-imposed censorship" ("Poetics" 8). In her analysis of poetic experiments in writing the self among Gulf women, Dhabya Khamis mulls over the manifestations of self-disciplining. She notes that their poetic utterances "fluctuate between outright expression of subversive impulses disputing cultural indoctrinations, and equivocation in order to accommodate society's expectations" (8).

In 1998, Faqir announces in the introduction to a collection of autobiographical essays by Arab women writers that the history of censorship of their writing is yet to be written (12). It was believed that their textual output never reaches the point where legal procedures impose sanctions against them, and censorship occurs before the circulation of the printed property in the literary market. The editor-in-chief intervenes early skirting over taboo issues, making deletions and excising phrases to cleanse the text and 'save' it from censures of hostile readership. Samia Mehrez remarks, "Censorship is renamed: protection" (191). In their personal accounts, Nawal el Sa'adawi ("Walking" 6) and Mounira al Fadel's (Salih 237) draw attention to the fact that their early works saw the light only after a process of redaction in which whole segments were omitted. Despite their exasperation at the deformity of their texts, both writers resigned themselves to publishers' arbitrary decisions urged by the desire to have their works reach the readers.

Arab communities, Magda al-Nowaihi argues, have a tendency to sweep shameful matters under the rug since exposing the negative qualities of the group is regarded as "a form of betrayal which gives ammunition to one's enemies" (487). When Rania al Baz published an account of a savage assault at the hands of her husband, she was criticized for speaking out. Her resolution to go public with her story, launching a campaign against wife battery in Saudi Arabia, is carried out at the expense of suffering the fate of an outcast in her country. Her father disowned her, and when she recovered from her injuries and sought to go back to her job as presenter of a program on state-owned television, she was rejected (www.farfesh.com).

Discussing rape experience is strictly off limits despite its damaging impact on society. The autobiography of Malika Mustazraf presents an account of sexual abuse with raw intensity that captures the effect of the traumatic violation of female body. The experience is detrimental to her entire being. She ponders, "Why do I disinter the past? Would this be a solace? I would never be comforted until I vomit out to their faces all the filth that has been interred inside me all those years" (5). Scenes of violence inflicted on her since childhood years are occasion to unmask and denounce the cankerous corruption gnawing at the heart of her society. Mustazraf writes, “Maybe there is no need to hang our dirty linen? No I will hang it for all to see. I don't care anymore. Whatever happens, I don't care what anyone would say" (5). Instead of appreciating Mustazraf's fearless and honest portrayal of social shortcomings, and valuing her courageous initiative in raising awareness of injustice, her account triggers a backlash. Religious coteries hurl anathemas at the text citing sayings from the prophetic tradition cautioning against defamation of one's community.

Traditional society fears the power of artistic creativity; and it is more alarming when the author is female. Various forms of surveillance adopt policies of containment to force female writers to conform to criterion regulating the legitimate topics for women to write about. For the most part, the constraints engendered the compulsion to cross defined borders (al $h u d d u d$ ), stimulated the female culture of inquiry and initiated new spaces and questions on women's creativity.

It is ironical that female narrative deemed by dominant discourse unworthy of literary significance, and restricted to putatively humble and unassuming genres, should trigger such 
unease. Disciplinary tactics carried out to dis-empower female textuality betrays an apprehension of the leverage of woman's voice, an awe of its potential to stir up subversive ideas, and the fear that what is published can enliven blunted sensibilities. It is worth noting that banning the circulation of a text on grounds of its coarseness, indecency, subversion or heresy and casting aspersions upon its author often impacts the text propitiously; it raises the curiosity of readers and contributes to the text's publicity and wide distribution.

In fact, Arab women's access to the discourse of autobiography is gorged and potholed. Narration can be conceived as an over-determined process; there is more at issue than the acquisition of the skills of the craft to tell her story to the world. In analyzing the modes Saudi women writers adopt for self-expression, Saddeka Arebi she detects an ideology of lack in the representation of female subjectivity that is attributable to multiple chains of signification in the state cultural politics (290). As they negotiate the autobiographical 'I', they carry within the complex socio-cultural designation of femininity. Most disparaging are the popular inscriptions that ascribe to women a natural propensity to perversion and shamefulness, and shoulder them with the responsibility for all unethical moral and social malaise.

In her exploration of the poetics of western female autobiography, Smith discerns that women, cross-culturally, write from the speaking posture which sub-consciously restrains impermissible impulses and mutes articulations that swerve from the normative mold ("Poetics" 53). In a study that deconstructs the erotic and legal aspects of the male-dominated theology, Fatnah Sabbah demonstrates that the female body is the site where the powerful group inscribes its system of domination, its taboos and its punishments (17). According to Sabbah, it is intimated in Islamic literature that the ideal of female desirability and key criteria of beauty are vested in silence; not to be a shaddaka (inveterate talker) (3). She wonders if this ideal and its corollary of the deprivation of power and the right to self-expression has "implications that go far beyond ... the sexual field" and gets intertwined with the political field (3). In fact, not only beauty and virtue and speaking softly are correlated, but also the prevalence of social order and well-being has been associated with women's wordless-ness and impalpable existence. Hence, the question arises: if women may be castigated for being heard and raising their voices, what would become of them if they bare the self in autobiographical narratives?

Significantly, Faqir blames the contributors to her volume of autobiographical essays for their prevarication. At the point of coming to grips with intimate details, their texts undergo redaction, and verbal expression becomes densely "lyrical, fictitious and illusory" (15). In her deliberations on Arab women's passion for communicating their experience, Shadia Qinawi argues that because putting themselves into their texts is reprehended as stigma, an intentional parading and flaunting of their compliance with conventional cultural identifications becomes a terra firma. However, this inclination, according to Qinawi, produces the gruesome self-inflicted malady of repressive silence for which authors of autobiography grope for an antidote (22). In this regard, Reda, at the outset of her personal account, admits that her self-text is consciously crafted. She states, "There will always be gaps and silences. Some memories would refuse to come forth, and stand naked in the light of day for everyone to inspect" (7). For Raja Alem, barging into taboo territory required another form of protective shield. Her semi-autobiographical narrative touches frequently on sensuality and female sexuality, yet such intimate drama of passionate experience hides in the faraway time and the elusive settings of legends and folktales.

In the Arabian Peninsula, when those disadvantaged by gender slacken the reins of the creative spirit, they are attacked aggressively by multiple forces of suppression. In her investigation of 
the location of Saudi women in the cultural map and the politics of their literary discourse, Arebi argues that the narrator adopts a variety of protective measures to "ensure a safe passage of their message" (297) to her readers. Because of the siege mentality of police state, women's texts manifest the "internalization of rules" (Arebi 297) as areas of indeterminacy erupt substituting words by blanks and gaps, in a "play on the notion of the unsaid" (Arebi 153). Hence, female narrative space emerges partially determined; full of intentional lapses and omissions, as well as opaque segments of equivocal expression and disjoined stream of thought.

Critics fling themselves into probing such fissures for meaningful insights and revelatory moments. Upon scrutinizing textual silences, Sabry Hafez finds that the unspoken is where the presence of ideology transpires most and where its suppressive impact is most forcefully felt (187). In her diagnostic inquiry, Nawar Golley suggests that attending to the silences of the self-text is a functional strategy in an analytical approach; she draws attention to the forceful eloquence underlying muted details (44). On another plane, Dalya Abudi contends that autobiographical writings containing areas of indeterminacy are "valuable documents not only for what they include but also for what they omit (94) ... Things left obscure or unspoken can provide critical insights into the writer's personality, family, and wider society" (92). In the gaps of the text, as Smith and Watson note, critics perform Lacanian readings. The other "internal to every autobiographical subject resides" ("Reading" 67) in the calculated procedure of selective inclusions and emphases.

For the Arab women, several assumptions dictate the politics of life-writing. The textual space of the 'I' is riddled with contentious debates. With the sword of Damocles hanging over their heads, autobiographers take refuge in equivocation and elliptical narration. Given the tug of warring dispositions, swinging between defiance and acquiescence, autobiographical expression abounds with textual trips and halts, vulnerabilities and stumbling, as the private voice battles its way through the religio-cultural cults.

In an unforgiving ambience of vigilant watchfulness and harsh judgment, an artist's sense of foreboding outweighs the impulse of unfettered expression. When writing, more often than not, a built-in guardian watches over any infractions of cultural norms, and interrupts the flow of unfiltered introspective effusions. Coming to the writer from within, self-censorship is equally coercive and its pressure gathers momentum in autobiography. Nevertheless, concealed subtleties and verbal gestures draw out sub-textual issues to the surface.

In a culture where women are subjected to the thralldom of 'eib (shameful), harram and muharram (the forbidden), one of the intractable issues is the problematic relationship between intimacy and distancing. Characteristically, the writer is engaged in a process of masking and unmasking. Self-narrative is ensconced between showing (al-zahir) and hiding (al-batin). The autobiographer seeks to express herself, but at the same time she doesn't want anyone to grasp her intentions. Thus, when it comes to dealing with the unspeakable, unsaid and unwritten, obliquity and circuitous routes are the most trodden tracks for Arab women autobiographers.

In fact, the Arab female autobiographical self is overburdened. Engagement with selfinscription is undertaken under coercive measures. Cultural mandates imposed on female lives make self-writing a dismal choice in which the author is constantly embattled. Exposing life experience for all to read and judge is regarded as self-incriminating indicting the autobiographer as brazen and contemptuous of venerated Arab mores. Moreover, portrayal of personal life struggles produces a stigmatizing effect detrimental to family respectability, 
bringing about slander that chases a woman to her grave and mars the reputation of her progeny.

On the whole, combating the normative order and its ritualized practices is a risky endeavor and more often a losing battle. In their engagement with the forces of conformity, several authors, across the different socio-cultural locations, undertake to recast concepts of right and wrong, virtue and vice as well as morality and immorality, in an unconventional mold. They define vice in terms of repression, duplicity, social hypocrisy and opportunistic exploitation of the weak. Enforcing oppressive codes on individual creativity is immorality per se. And possessing moral fiber, to them, means espousing freedom of thought, truthfulness and forthrightness.

Samia Kholoussi

University of Ain Shams in Cairo

\section{Endnotes:}

1. This is traceable to the medieval Islamic scholar, Ibn al-Qayyim al-Jawziyyah (12921349) who states: "And the Muslim should be aware of misusing 'I', 'mine' and 'I possess', because Iblees, Fir'aun and Qaaroon were indeed tried with these three expressions... \{I am better than him $\}$ (Surah Saad 38:76) is the statement of Iblees, \{mine is the dominion of Egypt\} (Surah Az-Zukhruf 43:51) is the statement of Fir'aun, and \{This has been given to me only because of knowledge I possess.) (Surah Al-Qasas 28:78) is the statement of Qaaroon. The best place to put 'I' is when the worshipper (of Allah) says: I am the sinful, mistaken, forgiveness seeking, confessing worshipper (of Allah). And "mine" when he says: the sin is mine, the fault is mine, the indigence is mine, the poverty is mine and the lowness is mine. And 'I possess' when he says: (Oh Allah) forgive me what I have committed (from sins) intentionally, jokingly, mistakenly, purposely, and I possess (within me is) all of that" (434-435) <http://www.salafidawah.com/beware-of-i-mine-and-i-possess.html>.

2. Adonis points out that in conservative platforms, the ruling establishment mandates unanimity of opinion since unorthodoxy generates rebellion. Those at variance with "the culture of the caliphate" are dubbed as "the people of innovation (ahl al-ihdath)"; heretics distorting deep-seated beliefs (76).

3. al-Tamimi cites el-Sa'adawi's defamation of her husband and other contemporary authors such as Idris and el-Zayyat (185).

4. Scholarly research probes various Qur'ānic exegeses to reveal presuppositions that masquerade as God-sent proscriptions, and assume the authority of the sacred. For the contribution of gender perspectives to intellectual formations in this field, see Heba Ezzat (1999), Nazira Zeineddine (1986-88, 1998) and Jinan Tamimi (2012).

5. al-Haydari discusses other instances of insolence such as el-Sa'adawi confessing to experiencing sexual harassment, admitting to engaging in extra-marital relations, and disavowing a woman's true nature by abstaining from marriage to pursue a career. He quotes her regrets stating, "And I found out that I wasted my life struggling ... Against whom? Against myself? (609)

6. Deliberations on cultural politics and power lead Jordan and Weedon to cogitate on several questions which bear relevance to Arab women's self-representation namely; whose narratives to be remembered and become official? Which subjectivities, images, voices and culture to be regarded as worthy of display? Who is representing whom and on what basis? How can narratives of the powerless compete in the market place of power to change the status quo?

7. For studies mulling over this issue, see Muhammad Fahmi 'Abdel-Wahhab, al harakat al nisa'iya fi al sharq wa silatuha bil-isti'imar wa al-sahyuniyya al 'alamiyya (Women's 
movement in the East and the influence of imperialism and Zionism). Cairo: Dar al'Itisam, 1979. 'Abdel-Wahab al-Messiri, Feminism versus Women's liberation Movements. Annandale, VA: United Association for Studies and Research. 1999, 2004.

8. "Double jeopardy," used by Blackburn in the context of African American female autobiography (146), pertains to Arab women who are defined by the category of woman and by the category Arab and third world citizens and in both cases they are isolated by hegemonic culture from the mainstream.

9. By the same token, Layla Ba'albaki's autobiographical novel brought upon her the wrath of the authorities who capitalized on her depiction of scenes that overturn moral conventions and espouse revolutionary ideas. For details of her trial, see Fernea (280290). Significantly, Dhabya Khamis' renditions of her life experience revealing her persistence in swimming against the tide with courage and honesty underline the defamation incumbent upon embracing progressive thought. Lina, Samar 'Attar's fictional memoir, was written in 1997 under the shadow of military governments during the fifties and early sixties. It was not accepted for publication until 1982. Even then, it was distributed in Beirut but banned in other Arab countries for embodying her "deep longing for freedom and never-ending struggle to throw off the restriction imposed by family, religion, culture and nation," thus stirring "controversies and objections from opposing quarters" ('Attar, 136). In fact, several autobiographies focus on documenting prison experience the authors suffered for their dissident stances. See Zainab Al-Ghazali, (1978), Farida al-Naqqash (1982, 1985), Safeynaz Kazem (1986) Inji Aflatun (1993), Latifa al-Zayyat (1996), Haifa Zangana (1991, 2009), etc...

\section{Works Cited:}

'Abdel-Rahman, 'A'ishah. 'Ala al-jisr: usturat al-zaman (On the bridge: a legend for all times). Cairo: Dar al-Hilal, 1967. Print.

'Abdel-Rahman, 'Awatef. Sifsafa: Sirah dhatiyah (Sifsafa: an autobiography). Cairo: General Egyptian Book Organization, 2012. Print.

Abouzeid, Leila. Return to childhood: the memoir of a modern Moroccan woman. Trans. Heather Logan Taylor. Austin: Center for Middle Eastern Studies at the U of Texas, 1998. Print.

Abu Deeb, Kamal. "The Collapse of Totalizing Discourse and the Rise of Marginalized/Minority Discourses." Tradition modernity and post-modernity in Arabic Literature. Ed. Issa J. Boullata et al. Leiden, Boston: Brill, 2000. 335-366. Print.

Abudi, Dalya. Mothers and Daughters in Arab Women's Literature: The Family Frontier. Leiden, Boston: Brill, 2011. Print.

Abu el-Naga, Shereen. 'Atifat al-ikhtilaf: qira'a fi kitabat niswiya (Reading of women's writing). Cairo: al-Hay'ah alMișrīyah al-'Āmmah lil-Kitāb, 1998. Print.

Accad, Evelyne. The Wounded Breast: Intimate Journeys Through Cancer. North Nelbourne, Vic.: Spinifex P., 2001. Print.

Adonis, An Introduction to Arab poetics. Trans. Catherine Cobham. Cairo: The American University in Cairo P., 1992. Print.

Aflatoun, Injy. Mudhakirat Injy Aflatoun (Memoirs). Al-Kuwayt: Dar al-Sabbah, 1993. Print.

Ahmed, Leila. A Border Passage: From Cairo to America - A Woman's Journey. New York: The Penguin Putnam Inc., 1999. Print.

al-'Ajlouni, Nayef. “al Sirah dhatiyah lefadwa tuqan” (The autobiography of Fadwa Tuqan). Mejallat Mo'tah lel Bouhuth wa al-Dirasat 10, no. 4, Oct. 1995. 89-106. Print.

'Alem, Raja. My Thousand and One Nights: A Novel of Mecca. New York: Syracuse UP, 2007. Print.

Al-Ghazali, Zainab. Return of the Pharaoh. Trans. Mokrane Guezzou. Leicester UK: the Islamic foundation, 1998. Print. 
al-Haydari, 'Abd-Allah. al-Sirah dhatiyah fi al-adab al-Saudi (Autobiography in Saudi Literature). Al-Riyadh: Dar alMa'arij al-Dawliyyah Lelnashr, 1998. Print.

al-Nowaihi, Magda. "Resisting Silence in Arab Women's Autobiography." International Journal of Middle East Studies 33 (2001): 477-502. Print.

al-Saqqaf, Abkar. Asda'a Moutafariqah: Sïrah dhātīyah (Sundry echoes: an autobiography). Cairo: Dar al-'Usour alJadidah, 2001. Print.

al-Sharouni, Youssef. Rihlati ma'a alqira'a (My journey with reading). Cairo: al Hay'a al'Amah Lelkitab, 1982. Print. al-Shaykh, Hanan. 2004. The Locust and the Bird: My Mother's Story. Trans. Roger Allen. London: Bloomsbury Publishing, 2009. Print.

a-Samman, Ghadah. al-Riwayah al-mustahilah: fusayfasa' Dimashqiyah (The Impossible novel: Damascene mosaic). Beirut: Manshurat Ghadah a-Samman, 1997. Print.

al-Tamimi, Amal. al-Sïrah dhātīyah al-nisa'iyah fi al-adab al-'arabi al-mo'asser (Female autobiography in contemporary Arab literature). Al-Dar al-Bayda': Dar Al-Markaz al-Thaqafi al-'Arabi, 2005. Print.

al-Tamimi, Jinan. Mafhum al-mar'ah bayna nașs al-tanzil wa-ta'wil al-mufassirin (The Concept of womanhood between the Qur'an as the word of God and exegetical commentaries). Beirut: Dar al-Farabi, 2012. Print.

al-Zayyat, Latifah. The Search. London: Quartet Books, 1996. Print.

'Arebi, Saddeka. Women and Words in Saudi Arabia: The Politics of Literary Discourse. New York: Columbia UP, 1994. Print.

'Attar, Maha Fa'iq. Hisad al-'umr: hikayati ma'a al-ayyam, 1931-1999 (Harvest of my lifetime). Damascus: M.F. al'Attar, 2000. Print.

'Attar, Samar. Lina: A Portrait of a Damascene Girl. Washington: Three Continents Press, 1994. Print.

"Translating the Exiled Self: Reflections on Translation and Censorship." Intercultural Communication Studies XIV: 4 (2005): 131-147. Print.

Ba’albaki, Laylá. Ana Ahiya (I live). Beirut: Simia, 1958. Print.

Badawi,'Abdel-Rahman. Al Mawt wa al 'Abqariyah (Death and mental brilliance). Cairo: Dār al-Qalam, 1961. Print.

Baisnée, Valérie. Gendered Resistance: The Autobiographies of Simone de Beauvoir, Maya Angelou, Janet Frame and Marguerite Duras. NY: Rodopi, 1997. Print.

---. Through the Long Corridor of Distance: Space and Self in Contemporary New Zealand Women's Autobiographies . New York : Rodop, 2014. Print.

Benstock, Shari. "Authorizing the Autobiographical." In Women, Autobiography, Theory: A Reader. Eds. Sidonie Smith and Julia Watson. Madison: U of Wisconsin P, 1998. 145-155. Print.

Berrada, Mohammed. "Arab North Africa." In Arab Women Writers: A Critical Reference Guide, 1873-1999. Eds. Radiwa 'Ashur, et al. Trans. Mandy McClure. Cairo: The American University in Cairo P, 2008. 235-253. Print.

Blackburn, Regina. "In Search of the Black Female Self: African American Women's Autobiography and Ethnicity." In Women's Autobiography: Essays in Criticism. Ed. Estelle Jelinek. Bloomington: Indiana UP. 1980, 33-48. Print.

Brodzki, Bella. "Mothers, Displacement, and Language." In Women, Autobiography, Theory: A Reader. Eds. Sidonie Smith and Julia Watson. Madison: U of Wisconsin P, 1998. 156-159. Print.

Butler, Judith. Giving an Account of Oneself. New York: Fordham UP, 2005. Print.

Eakin, Paul. “Mapping the Ethics of Life Writing.” In The Ethics of Life Writing. Ed. Paul John Eakin. Cornell UP 2004. 1-18. Print.

el-'Araji, Nazik. Sawt al'unthah (The female voice). Damascus: Dar al'Ahali, 1997. Print.

el-'Assal, Fat-hiyya. Hudn al 'Umr I-III (In the arms of life). Cairo: al-Hay'ah al-Mișriyah al-'Ammah lil-Kitab, 2002. Print.

el-Baz, Rania. "limaza tabara' waled Rania el-Baz minha?" (Why did Rania's father disown her?) N.p. Web. <http://www.farfesh.com/Display.asp?catID=159\&mainCatID=158\&sID=11760>.

el-Bouih, Fatna. Talk of Darkness. Austin: Center for Middle Eastern Studies, 2008. Print. 
el-Dahi, Mohammad. "Mahka alhyah al-nisa'yah belmaghreb." (Women's narrative in Maghreb). Etudes-essaie 328. 1Nov. 2010. <http://www.minculture.gov.ma/index.php>.

el-Muji, Sahar. Dariyah. Cairo: Dar al-Shuruq, 1998. Print.

el-Sa'adawi, Nawal. Qadaya al-mar'ah wa al-siyasah (Issues in women, thought and politics). Cairo: al-'Arabiyya Lel-Tiba'a wa al-Nashr, 2002a. Print.

---. Walking Through Fire: A Life of Nawal el-Saadawi. London: Zed Books. 2002b. Print.

el-Saddah, Hoda. "Reconsidering the History of Feminism and Anti-colonialism: A Reading of Mounira Thabet's Memoirs." In History in literature: Proceedings the Third International Symposium on Comparative Literature. Cairo: U of Cairo P, 1995. 449-464. Print.

Ezzat, Heba. "Women and Ijtihad: Towards a New Islamic Discourse." Alif: Journal of Comparative Poetics 19 (1999): 96-120. Print.

Faqir, Fadia. "Introduction." In The House of Silence: Autobiographical Essays by Arab Women Writers. Ed. Fadia Faqir. Reading: Garnet Publishers, 1998. 1-23. Print.

Fawwaz, Zeinab. Husn al'awaaqib aw ghadat al zahrah (The happy ending). Cairo: Matba'at Hindiya, 1895.

Fernea, Elizabeth. Middle Eastern Women Speak. The Dan Danciger Publication Series: U of Texas P, 1977. Print.

Friedman, Susan Stanford. "Women's Autobiographical Selves: Theory and Practice." In Women, Autobiography, Theory: A Reader. Eds. Sidonie Smith and Julia Watson. Madison: U of Wisconsin P, 1998. 72-82. Print.

Gammel, Irene. Confessional Politics: Women's Sexual Self-Representations in Life Writing and Popular Media, ed. Irene Gammel. Carbondale and Edwardsville: Southern Illinois P, 1999. Print.

Garam, Zuhur. Fi diyafat al-raqabah : min khilal al-tajribah al-ibda'iyah li-Layla al-'Uthman (A guest of censorship). al-Rabaț: Jaridat al-Zaman, 2001. Print.

---. Al-Sard al-nisa'i al-'arabi: moqarabah fi al-mafhoum wa al-khitab (Arab Female Narrative). Al-Dar al-Bayda: Sharikat al-Nashr wa al-Tawzie', 2004. Print.

Genette, Gerard. "Structure and Functions of the Title in Literature." Critical Inquiry 14, 4 (1988): 708-720. Print.

Ghamdi, Saleh. "Autobiography in Classical Arabic Literature: An Ignored Genre.” Ph.D. diss., Indiana U, 1989. Print.

Ghudhami, 'Abd-Allah. al Mar'a wa al lughah (Woman and language). Beirut and al Dar al Bayda': al Markaz al Thaqafi al'Araby, 1996. Print.

Ghusn, Aminah. Naqd al-maskut 'anhu fi khitab al-mar'ah wa-al-jasad wa-al-thaqafah (Critique of the silenced: the discourse of women). Damascus: al-Mada, 2002. Print.

Gilmore, Leigh. “Autobiographics.” In Women, Autobiography, Theory: A Reader. Eds. Sidonie Smith and Julia Watson. Madison: U of Wisconsin P, 1998. 183-189. Print.

Golley, Nawar. Reading Arab Women's Autobiography: Shahrazad Tells Her Story. Austin: U of Texas P, 2003. Print.

Grace, Daphne, “Arab Women Write the Trauma of Exile and Imprisonment." In Arab Women's Lives Retold: Exploring Identity Through Writing. Ed. Nawar Golley. New York: Syracuse UP, 2007. 181-200. Print.

Hafez, Sabry. "Binyet al khitab al niswy" (Feminist discourse). In Latifah al Zayyat: Al'Adab wa al Wattan (Literature and the nation). Ed. Sayyed al Bahrawy. Cairo: Nour Dar al Mar'a al'Arabiyah Lelnashr, 1996. 185-187. Print.

Hammud, Majidah. al-Khitab al-qisasi al-nisawi: namadhij min Suriyah (Syrian feminist discourse). Beirut: Dar alFikr al-Mu'așir, 2002.

Hassan, Rosa. al 'Ihteraq fi atoon al-kitabah: 'athman tadfa'aha al-nisa'a (The cauldron of writing). 13 Jun. 2006. N.p., Web. $<$ http://www.pewesr.org $>$.

Heilbrun, Carolyn. Writing a Woman's Life. NY: Norton, 1988. Print.

Jawziyyah, Ibn al-Qayyim, Zad al-Ma'ad (Provisions for the hereafter). Eds. Shu'ayb al Arna'ot and 'Abdel-Qader al-Arna'ot. Cairo: Mo'asasat al-Risalah, 2009. Print.

Jordan, Glenn and Chris Weedon, Cultural Politics: Class, Gender, Race and the Postmodern World. Cambridge, Mass.: Blackwell Publishers, 1995. Print. 
Joseph, Suad (ed.) Intimate Selving in Arab Families: Gender, Self, and Identity. New York: Syracuse UP, 1999. Print.

Kanafani, Afaf. Nadia Captive of Hope: Memoir of an Arab Woman. London: M.E. Sharpe,1999.

Khamis, Dhabya. Ibtisamat makira wa qisas ukhra (Deceptive smiles and other stories). Kuwayt: al-Rabi'an Publishing Company, 1996. Print.

---. al-Dhat al-unthawiyah min khil'ali sha'irat hadathiyat fi al-Khalij al-'Arabi : dirasah fi al-naqd al-adabi al-nisa'i (Feminist self in female Gulf poetry). Damascus: Al-Mada Publishing company 1997. Print.

--- al-Hayah ka-ma hiya: sirah riwa'iyah (Life as it is: an autobiographical novel). Beirut: Dar al-Adab lil-Nashr waal-Tawzi', 2011. Print.

Kharis, Samihah. 'Ala janaḥ al-țayr: sirat al-mada'in al-Ladhiqiyah (Autobiography of the cities of Latakia). Amman: Dar al-Hiwar lil-Tiba'ah wa-al-Nashr wa-al-Tawzi', 2012. Print.

Mehrez, Samia. "Poetic Experimentation and the Institution: The Case of Ibda'a 77 and Aswat." In The View from Within: Writers and Critics on Contemporary Arabic Literature. Eds. Ferial Ghazoul and Barbara Harlow. Cairo: The American U in Cairo P, 1994. 177-196. Print.

Messaoudi, Khalida. Unbowed: An Algerian Woman Confronts Islamic Fundamentalism. Trans. Anne C. Vila. Philadelphia: U of Pennsylvania P, 1998. Print.

Milani, Farzaneh. "Veiled Voices: Women's Autobiographies in Iran.” In Women's Autobiographies in Contemporary Iran. Ed. Afsaneh Najmabadi. Cambridge: Harvard UP, 1990. 1-16. Print.

---. Veils and Words: The Emerging Voices of Iranian Women Writers. NY: Syracuse UP, 1992. Print.

Mills, Claudia . "Friendship, Fiction, and Memoir: Trust and Betrayal in Writing from One's Own Life". In The Ethics of Life Writing. Ed. Paul John Eakin. Cornell UP, 2004. 101 - 119. Print.

Mo'etasem, Mohamad. al Mar'ah wa al sard (Woman and narration). Al Dar al Bayda': Dar al Thaqafah, 2004. Print. Mostaghanemi, Ahlam. "Writing Against Time and History." In The House of Silence: Autobiographical Essays by Arab Women Writers. Ed. Fadia Faqir. Reading: Garnet Publishers, 1998. 79-90. Print.

Mustazraf, Malikah. Jarah: al-ruh wa-l-Jisd (Lacerations of the soul and body). Kenitra: Accent, 1999. Print.

Nagi, Sawsan. Al wa'ey bel kitabah fi al khitab alnisa'I al 'araby a'mo'aser (The importance of writing: Arab female discourse). Cairo: al-Majlis al-A'ala Lelthaqafah, 2004. Print.

Na'na, Hamidah. Min dafater imra'a 'arabiya (Notebooks of an Arab woman). Beirut: al Mo'asasah al'Arabiyah Lel Dirasa, 1992. Print.

al-Naqqash, Farida. Sijn ... al-wațan (Prison ... the nation). Beirut: Dār al-Kalimah lil-Nashr, 1982. Print.

Al Sijn dam'atan ... wa warda (Prison two tears ... and a rose). Cairo: Dar al-Mostaqbal al-Arabi, 1985. Print.

Qazem, Safinaz. 'An al-Sijn wa al-Huryya (On prison and freedom). Cairo: al-Zahra'a lel'E'lam al'Araby, 1986. Print.

Qinawi, Shadia. al Mar'ah al 'arabiyah wa foras al 'ibda' (Arab woman and the space of creativity). Cairo: Dar Qiba'a lel Tiba'ah wa al-Nashr wa al-Tawzi'e, 2000. Print.

Rida, Jalilah. Șafahat min hayati (My life). Cairo: Dar al-Hilal, 1986. Print.

Sabbah, Fatna. Woman in the Muslim Unconscious. Trans. Mary Jo Lakeland. NewYork: Pergamon, 1984. Print.

Sabri, Musa. Khamsun 'aman fi qitar al-sihafah: Mudhakkirat Musa Sabri (Memoirs). Cairo: Dar al-Shuruq, 1992. Print.

Salih, Layla Mohammad. Adab al mara'a fi al jazirah wa al khlij al 'arabi (Women's literature in Arabia). Al-Riyadh: Matabi' al-Yaqzan, 1983. Print.

Sha'aban, 'Abdel-Hussein. "Khaled Ali al-Saleh - Ala tariq alnawayah altayebah: tajrebti ma'a hizb al ba'ath." (Pursuing good intentions: the case of al Ba'ath party). al Hiwar al Motamaden 221. 7 Mar. 2008. N.p., Web. $<$ www.ahewar.org/debat/show.art.asp?aid=127271>.

Shafik, Doria. “Memoirs.” 1956, 1975 (English); 1960 (French). MS. Private collections of Jehan Ragai and Aziza Ellozy, Cairo.

Smith, Sidonie and Julia Watson. Reading Autobiography: A Guide for Interpreting Life Narratives. Minneapolis: U Minnesota P, 2001. Print. 
Smith, Sidonie. A Poetics of Women's Autobiography: Marginality and the Fictions of Self-Representation. Bloomington: Indiana UP, 1987. Print.

Spacks, Patricia. "Selves in Hiding." In Women's Autobiography:Essays in Criticism. Ed. Estelle C. Jelinek. Bloomington: Indiana UP, 1980. 112-132.

Stagh, Marina. The Limits of Freedom of Speech: Prose Literature and Prose Writers in Egypt under Nasser and Sadat. Acta Universitatis Stockholmiensis. Almqvist \& Wiksell International, 1993. Print.

Stanton, Domna. "Autogynography: Is the Subject Different?" In Women, Autobiography, Theory: A Reader. Eds. Sidonie Smith and Julia Watson. Madison: U of Wisconsin P, 1998. 131-144. Print.

Taha, Ibrahim. "The Power of the Title: Why Have You Left the Horse Alone by Mahmoud Darwish." Journal of Arabic and Islamic Studies, 3 (2000): 66-83. Print.

Tahawi, Miral. Imra'at al-araq: sirah thaqafiyah (An Insomniac woman: a cultural autobiography). Cairo: al-Hay'ah al-Mișrīyah al-'Āmmah lil-Kitāb, 2012. Print.

Tawfiq, Ashraf. I'tirafat Nisa' Adibat (Confessions of literary women). Cairo: Dar al-Amin, 1998. Print.

Tax, Meredith, Marjorie Agosin et.al. The Power of the Word: Culture, Censorship, and Voice. New York: Women's World, 1995. Print.

Tuqan, Fadwa. Mountainous Journey. Trans. Salma Khadra Jayyusi. Minnesota: Graywolf Press, 1990. Print.

'Usayran, Layla. Shara'it Mulawwanah min hayati (My life). London: Riad el-Rayyes Books Ltd, 1994. Print.

'Uthman, 'Afif. Narjis al-Sïrah dhätīyah (the Narcissism of Autobiography). 10 Apr. 2010.

$<$ http://www.terezia.org>.

'Uthman, Layla. al Muhakamah (The trial). Damascus: Dar al-Mada, 2000. Print.

Zangana, Haifa. Through the Vast Halls of Memory. Paris: Hourglass, 1991. Print.

Dreaming of Baghdad. New York: Feminist P., 2009. Print.

Zeineddine, Nazira. Al-sufur wa al-hijab (Unveiling and veiling, 1928). Damascus: Dar al-Mada, 1998. Print.

---. Al-fatat wa al shuyukh (The girl and the shaykhs, 1929). Damascus: Dar al-Mada, 1988-86. Print.

Zénié-Ziegler, Wédad. In Search of Shadows: Conversations with Egyptian Women. London: Zed Books, 1988. Print.

Ziyadah, Mai. Muthakirat Mai: Mai fi muthakaratiha (Memoirs). Cairo: Dar al-Rihani lel-Tiba'ah wa al-Nashr, 1956. Print. 